\title{
PENEGAKAN HUKUM UNDANG-UNDANG INFORMASI DAN TRANSAKSI ELEKTRONIK TERHADAP HUKUMAN PENGGUNA MEDIA SOSIAL UJARAN KEBENCIAN
}

\author{
Toni \\ Dosen Fakultas Keguruan dan Ilmu Pendidikan (FKIP), Universitas Labuhanbatu \\ E-mail: toni300586@gmail.com
}

\begin{abstract}
ABSTRAK
Penelitian ini bertujuan untuk penegakan hukum undang-undang informasi dan transaksi elektronik (UU ITE) terhadap hukuman pengguna media sosial ujaran kebencian. Jenis Penelitian Hukum Normatif. Metode pendekatan yang digunakan adalah perundangundangan dan kajian pustaka terkait judul peneliti, sedangkan metode menggunakan analisis Kualitatif dengan cara menganalisis hasil bahan penelitian yang relevan dengan tujuan penelitian. Hasil penelitian tentang ujaran kebencian terdapat pada pengaturan (UU ITE) No.19 Tahun 2016 atas Perubahan Undang-Undang No. 11 Tahun 2008 tentang Informasi dan Transaksi Elektronik, dimana bagi pelaku pengguna media sosial ujaran kebencian diatur dalam Pasal.28 ayat (2) isinya" Setiap Orang dengan sengaja dan tanpa hak menyebarkan informasi yang ditujukan untuk menimbulkan rasa kebencian atau permusuhan individu dan/atau kelompok masyarakat tertentu berdasarkan atas suku, agama, ras, dan antar golongan (SARA). Ancaman Hukuman Pasal 45 A ayat (2) isinya" Setiap Orang yang dengan sengaja dan tanpa hak menyebarkan informasi yang ditujukan untuk menimbulkan rasa kebencian atau permusuhan individu dan/atau kelompok masyarakat tertentu berdasarkan atas suku, agama, ras, dan antargolongan (SARA) sebagaimana dimaksud dalam Pasal 28 ayat (2) dipidana dengan pidana penjara paling lama 6 (enam) tahun dan/atau denda paling banyak Rp1.000.000.000,00 (Satu miliar rupiah). Sedangkan upaya penanggulangan pelaku pengguna media sosial ujaran kebencian, diatur dalam Surat Edaran Kapolri Nomor SE/6/X/2015, tentang Penanganan Ujaran Kebencian ( Hate Speech). Untuk mengedepankan Fungsi Binmas dan Polmas, dimana peran dari kepolisian diharapkan untuk memberikan sosialisasi dan penyuluhan hukum tentang ujaran kebencian dimasyarakat melalui toko agama, toko masyarakat, toko pemuda dan akademisi untuk optimalisasi tindakan represif atas ujaran kebencian. Selanjutnya peran perangkat pemerintahan diharapkan untuk mengkondusifkan daerah masing masing melalui Kecamatan, Kelurahan/Desa, dan Perangakat RT/RW sebagai wadah pertama dalam hubungan emosional dimasyarakat.
\end{abstract}

Kata kunci : UU ITE, Hukuman, Ujaran Kebencian. 
2303-2863 (P-ISSN)

\section{PENDAHULUAN}

Mengenai penegakan hukum terhadap UU ITE merupakan tanggung jawab besar negara untuk melindungi masyarakat berbangsa dan bernegara. Kehidupan manusia saat ini dihadapkan dengan kemajuan jaman yang pesat. Dapat dilihat hampir seluruh cakuman masyarakat Indonesia menggunakan aplikasi androit atau jaringan internet untuk mendukung kebutuhan masyarakat. Baik kebutuhan komunikasi, pendidikan, ekonomi dan kebutuhan lainya hampir dilakukan dengan menggunakan komunikasi digital.

Dalam percepatan lajunya pengguna media sosial butuh adanya filter untuk batasan-batasan positif bagi pengguna media sosial yaitu dibatasi dengan lahirnya UU ITE No. 19 Tahun 2016 atas Perubahan Undangundang No. 11 Tahun 2008 tentang Informasi dan Transaksi Elektronik. Komunikasi dalam media sosial butuh konten positif, agar tidak mendatangkan hujatan dan ujaran kebencian dalam komunikasi baik pripat maupun public. Dapat dilihat dalam beberapa kasus media sosial dimana dihadapkan dengan persoalaan ujaran kebencian bahkan jika kita pengguna media sosial sering sekali kita melihat banyaknya prilaku pengguna media sosial yang tidak menggunakan internet dengan pola pikir yang baik. Banyaknya kasus kita lihat tentang ujaran kebencian seperti yang dilarang pada UU ITE Pasal 27 ayat (1, 2, 3 dan 4). Mengenai mentransfer atau mendistribusikan konten asusila yang mengundang pornografi, mendistribusikan konten perjudian, mendistribusikan konten penghinaan dan pencemaran nama baik, dan pemerasan dan pengancaman.

Pendapat Gunawan, Heri (2020:77), Berkaitan dengan perkembangan teknologi informasi dan berbagai media sosial yang ada, konstitusi mengatur kebebasan berpendapat melalui berbagai saluran informasi yang ada seperti yang ditegaskan dalam Pasal 28F UndangUndang Dasar 1945 Amandemen Kedua yang menyebutkan, bahwa : "Setiap orang berhak untuk berkomunikasi dan memperoleh informasi untuk mengembangkan pribadi dan lingkungan sosialnya, serta berhak untuk mencari, memperoleh, memiliki, menyimpan, mengolah dan menyampaikan informasi dengan menggunakan segala jenis saluran yang tersedia".

Selanjutnya dapat dilihat pada ketentuan UU ITE Pasal 28 ayat (1 dan 2) menerangakan dilarang bagi pengguna media sosial untuk memberikan berita bohong dan menyesatkan sehingga merugikan konsumen dalam transaksi elektronik dan selanjunya setiap orang dilarang untuk menmbulkan rasa kebencian, permusuhan pribadi, kelompok, suku, agama, ras dan antar golongan (SARA). Dalam lajunya perkembangan zaman melalui media sosial, hukum harus dapat menjawab tantangan dinamika permasalahan hukum tentang ujaran kebencian pada saat ini. Hukum harus menjadi filter yang dapat diandalkan untuk menjaga ketertiban dalam dunia media sosial. Budaya konsumtif bangsa Indonesia yang gemar dalam mengakses smarphone untuk keperluan kebutuhan bermedia sosial diantaranya yaitu Twitter, whatsaap, facebook, instagram, tiktok dan media sosial lainnya yang dapat merugikan orang lain jika tidak di manfaatkan sesuai dengan kebutuhan. Untuk itu dengan hadirnya UU ITE No. 19 Tahun 2016 atas Perubahan Undang-undang No. 11 Tahun 2008 tentang Informasi dan Transaksi Elektronik. UU ITE tersebut dapat memberikan solusi positif untuk membendung budaya prilaku yang tidak baik dalam penggunaan media sosial. Sebaliknya dunia siber atau cyberculture tidak terlepas dari kebutuhan teknologi internet 
untuk menjerat para prilaku kejahatan dunia maya yang dianggap dapat menjadi ancaman Negara jika tidak diberikan penindakan hukuman yang tegas oleh penegak hokum. Pengguna media sosial dapat memposting konten berupa tulisan, video, suara maupun gambar secara bebas yang dapat disebarluaskan kepada siapapun , dimanapun dan kapanpun dengan bantuan jaringan internet. Tidak jarang pengguna media sosial dapat menyalahgunakan media sosial sebagai sarana untuk menyampaikan luapan emosional mereka dengan cara menyebar berita palsu, menjatuhkan orang lain, bahkan menyebar kebencian kepada orang lain atau suatu kelompok.

\section{LANDASAN TEORI}

Menurut Watie, (2011:69), Media sosial telah banyak merubah dunia. Memutarbalikkan banyak pemikiran dan teori yang dimiliki. Tingkatan atau level komunikasi melebur dalam satu wadah yang disebut jejaring sosial/media sosial. Konsekuensi yang munculpun juga wajib di waspadai, dalam arti media sosial semakin membuka kesempatan tiap individu yang terlibat di dalamnya untuk bebas mengeluarkan pendapatnya. Akan tetapi kendali diri harusnya juga dimiliki, agar kebebasan tidak melanggar batasan dan tidak menyinggung pihak lain.

Menurut M. Choirul Anam dan Muhammad Hafiz (2015-344). Dalam konteks ujaran kebencian dan permusuhan, Kovenan Internasional Sipil-Politik (Sipol) menegaskan dalam Pasal 20, bahwa;

1. Segala propaganda untuk perang harus dilarang oleh hukum,

2. Segala tindakan yang menganjurkan kebencian atas dasar kebangsaan, ras atau agama yang merupakan hasutan untuk melakukan diskriminasi, permusuhan atau kekerasan harus dilarang oleh hukum.

Pendapat Camden (2009:11), Negara sebaiknya mengadopsi legislasi yang melarang advokasi kebencian antar bangsa, ras atau agama yang mengandung penyebarluasan diskriminasi, kebencian atau kekerasan (ungkapan kebencian). Sistem hukum nasional sebaiknya memperjelas, baik secara eksplisit maupun interpretasi yang otoritatif, bahwa:

1. Istilah 'kebencian' dan 'kekerasan' mengacu pada perasaan merendahkan, menghina, membenci yang kuat dan irasional yang ditujukan kepada kelompok sasaran tertentu.

2. Istilah 'advokasi' mensyaratkan adanya maksud untuk mempromosikan kebencian secara terbuka terhadap kelompok sasaran tertentu.

3. Istilah 'penyebarluasan' mengacu pada pengungkapan pernyataan terhadap kelompok kebangsaan, ras atau agama tertentu yang menciptakan resiko diskriminasi, kebencian dan kekerasan yang mendesak terhadap orang-orang yang termasuk dalam kelompokkelompok tersebut.

4. Mempromosikan identitas kelompok secara positif oleh komunitas-komunitas berbeda tidak termasuk dalam ungkapan kebencian.

Menurut Chairul Huda, ( 2011:70), Penegakan hukum atas dugaan terjadinya tindak pidana ujaran kebencian berdasarkan Surat Edaran Kapolri Nomor SE/06/X/2015 tentang Ujaran Kebencian (Hate Speech) mengacu pada ketentuan :

1. Pasal 156 KUHP 


\section{Pasal 157 KUHP}

3. Pasal 310 KUHP

4. Pasal 311 KUHP

5. Pasal 28 ayat (2) junto Pasal 45 ayat (2) UU Nomor 11 Tahun 2008 tentang Informasi dan Transaksi Elektronik.

6. Pasal 16 UU Nomor 40 Tahun 2008 tentang Penghapusan Diskriminasi Ras dan Etnis Pertanggungjawaban pidana adalah pertanggungjawaban orang terhadap tindak pidana yang dilakukannya. Tegasnya, yang dipertanggungjawabkan orang itu adalah tindak pidana yang dilakukannya. Dengan demikian, terjadinya pertanggungjawaban pidana karena telah ada tindak pidana yang dilakukan oleh seseorang.

Bahwa menurut Surat Edaran Kapolri Nomor. 6/X/2015 tentang Penanganan Ujaran Kebencian ( $H A T E$ SPEECH). Tanggal 8 Oktober 2015 pada point (F). dijelaskan Bahwa ujaran kebencian dapat berupa tindak pidana yang diatur dalam Kitab Undang-Undang Hukum Pidana (KUHP) dan ketentuan pidana yang lainnya diluar KUHP, yang berbentuk antara lain :

1. Penghinaan

2. Pencemaran nama baik

3. Penistaan

4. Perbuatan tidak menyenangkan

5. Memprovokasikan

6. Menghasut

7. Penyebaran berita Bohong

Dan semua tindakan diatas memiliki tujuan atau bisa berdampak pada tindak diskriminasi, kekerasan, penghilangan nyawa, dan atau konflik sosial. Halaman (2).
Surat Edaran Kapolri Nomor. 6/X/2015 tentang Penanganan Ujaran Kebencian ( HATE SPEECH). Tanggal 8 Oktober 2015. Pada point Menerangkan Bahwa ujaran kebencian sebagaimana di maksud diatas bertujuan untuk menghasut dan menyulut kebencian terhadap individu dan atau kelompok masyarakat dalam berbagai komunitas yang dibedakan dari aspek:

1. Suku

2. Agama

3. Aliran keagamaan

4. Keyakinan atau kepercayaan

5. Ras

6. Antar golongan

7. Warna kulit

8. Etnis

9. Gender

10. Kaum difabel ( cacat )

11. Orientasi seksual. Halaman (3)

Menurut Undang-undang No. 19 Tahun 2016 atas Perubahan Undang-undang No. 11 Tahun 2008 tentang Informasi dan Transaksi Elektronik.

Pasal 1 ayat (5). Sistem Elektronik adalah "serangkaian perangkat dan prosedur elektronik yang berfungsi mempersiapkan, mengumpulkan, mengolah, menganalisis, menyimpan, menampilkan, mengumumkan, mengirimkan, dan/atau menyebarkan Informasi Elektronik"

Pasal 45

(1) Setiap Orang yang dengan sengaja dan tanpa hak mendistribusikan dan/atau mentransmisikan dan/atau membuat dapat diaksesnya Informasi Elektronik dan/atau Dokumen Elektronik yang memiliki muatan yang melanggar kesusilaan sebagaimana dimaksud dalam Pasal 27 ayat (1) dipidana dengan pidana penjara paling lama 6 (enam) tahun dan/atau denda paling banyak Rp 


\subsubsection{0,00 (Satu miliar rupiah).}

(2) Setiap Orang yang dengan sengaja dan tanpa hak mendistribusikan dan/atau mentransmisikan dan/atau membuat dapat diaksesnya Informasi Elektronik dan/atau Dokumen Elektronik yang memiliki muatan perjudian sebagaimana dimaksud dalam Pasal 27 ayat (2) dipidana dengan pidana penjara paling lama 6 (enam) tahun dan/atau denda paling banyak Rp 1.000.000.000,00 (Satu miliar rupiah).

(3) Setiap Orang yang dengan sengaja dan tanpa hak mendistribusikan dan/atau mentransmisikan dan/atau membuat dapat diaksesnya Informasi Elektronik dan/atau Dokumen Elektronik yang memiliki muatan penghinaan dan/atau pencemaran nama baik sebagaimana dimaksud dalam Pasal 27 ayat (3) dipidana dengan pidana penjara paling lama 4 (empat) tahun dan/atau denda paling banyak Rp 750.000.000,00 (Tujuh ratus lima puluh juta rupiah).

(4) Setiap Orang yang dengan sengaja dan tanpa hak mendistribusikan dan/atau mentransmisikan dan/atau membuat dapat diaksesnya Informasi Elektronik dan/atau Dokumen Elektronik yang memiliki muatan pemerasan dan/atau pengancaman sebagaimana dimaksud dalam Pasal 27 ayat (4) dipidana dengan pidana penjara paling lama 6 (enam) tahun dan/atau denda paling banyak Rp1.000.000.000,00 (Satu miliar rupiah).

\section{METODE PENELITIAN}

Bahwa Penulisan penelitian ini menggunakan jenis Penelitian Hukum
Normatif. Dengan metode pendekatan yang digunakan adalah perundang-undangan dan kajian pustaka terkait judul peneliti, sedangkan metode menggunakan analisis kualitatif dengan cara menganalisis hasil bahan penelitian yang relevan dengan tujuan penelitian.

\section{Bahan Hukum Penelitian:}

a) Hahan Hukum Primer:

Bahan hukum primer, yaitu bahan yang mempunyai kekuatan hokum mengikat secara yuridis yang terdiri dari peraturan perundang-undangan yang terkait dengan penelitian ini, yaitu:

1. Kitab Undang-Undang Hukum Pidana (KUHP).

2. Undang-Undang Nomor 19 Tahun 2016 Tentang Perubahan Atas Undang-Undang Nomor 11 Tahun 2008 Tentang Informasi Dan Transaksi Elektronik.

3. Surat Edaran Kapolri Nomor. 6/X/2015 tentang Penanganan Ujaran Kebencian ( $H A T E$ SPEECH). Tanggal 8 Oktober 2015.

4. Dan data pendukung lainya.

b) Bahan Hukum Skunder:

Bahan hukum skunder yaitu: bahan yang menjelaskan terhadap bahan hukum primer, yaitu terdiri dari buku-buku, literatur, berita, jurnal maupun karya ilmiah yang berhubungan dengan penelitian

\section{HASIL DAN PEMBAHASAN}

1. Penegakan Hukum UndangUndang Informasi Dan Transaksi Elektronik Terhadap Pelaku 


\section{Pengguna Media Sosial Ujaran Kebencian?}

Bahwa dalam kasus penegakan hukum terhadap pelaku pengguna media sosial ujaran kebencian Harus diatur secara tegas dalam aturan hukum secara normatif dan

Elektronik, dan Surat Edaran Kapolri Nomor. 6/X/2015 tentang Penanganan Ujaran Kebencian (HATE SPEECH). Tanggal 8 Oktober 2015. Adapun mengenai pengaturan ujaran kebencian yaitu:

\section{Tabel: Keterangan Ujaran Kebencian:}

\begin{tabular}{|c|c|c|c|}
\hline No. & $\begin{array}{c}\text { Undang-Undang/ Surat Edaran } \\
\text { Kapolri }\end{array}$ & Pasal/Halaman & Keterangan \\
\hline 1 & $\begin{array}{l}\text { UU No.19 Tahun } 2016 \text { atas Perubahan } \\
\text { Undang-Undang No. } 11 \text { Tahun } 2008 \\
\text { tentang Informasi dan Transaksi } \\
\text { Elektronik }\end{array}$ & Pasal 28 ayat (2) & $\begin{array}{l}\text { Setiap Orang dengan sengaja dan tanpa hak } \\
\text { menyebarkan informasi yang ditujukan untuk } \\
\text { menimbulkan rasa kebencian atau permusuhan } \\
\text { individu dan/atau kelompok masyarakat } \\
\text { tertentu berdasarkan atas suku, agama, ras, dan } \\
\text { antar golongan (SARA). }\end{array}$ \\
\hline 2 & $\begin{array}{llr}\text { Surat Edaran Kapolri } & \text { Nomor } \\
\text { SE/06/X/2015 } & \text { tentang } & \text { Ujaran } \\
\text { Kebencian (Hate } & \text { Speech) } & \text { mengacu } \\
\text { pada ketentuan: } & & \end{array}$ & $\begin{array}{l}\text { Halaman } \\
\text { huruf (b) }\end{array}$ & $\begin{array}{l}\text { 1. Pasal } 156 \text { KUHP } \\
\text { 2. Pasal } 157 \text { KUHP } \\
\text { 3. Pasal } 310 \text { KUHP } \\
\text { 4. Pasal } 311 \text { KUHP } \\
\text { 5. Pasal } 28 \text { ayat (2) jounto. Pasal } 45 \text { ayat (2) } \\
\text { UU Nomor } 11 \text { Tahun } 2008 \text { tentang } \\
\text { Informasi dan Transaksi Elektronik. } \\
\text { 6. Pasal } 16 \text { UU Nomor } 40 \text { Tahun } 2008 \text { tentang } \\
\text { Penghapusan Diskriminasi Ras dan Etnis. }\end{array}$ \\
\hline 3 & $\begin{array}{l}\text { Surat Edaran Kapolri Nomor } \\
\text { SE/06/X/2015 tentang Ujaran } \\
\text { Kebencian (Hate Speech) disebutkan } \\
\text { tentang Ujaran Kebencian (Hate } \\
\text { Speech) dapat berupa tindak pidana } \\
\text { yang di atur dalam KUHP dan } \\
\text { ketentuan-ketentuan pidana lainnya di } \\
\text { luar KUHP, yang berbentuk: }\end{array}$ & $\begin{array}{l}\text { Halaman } \\
\text { huruf(f) }\end{array}$ & $\begin{array}{l}\text { 1. Penghinaan } \\
\text { 2. Pencemaran nama baik } \\
\text { 3. Penistaan } \\
\text { 4. Perbuatan tidak menyenangkan } \\
\text { 5. Memprovokasikan } \\
\text { 6. Menghasut } \\
\text { 7. Penyebaran berita Bohong }\end{array}$ \\
\hline 4 & $\begin{array}{llr}\text { Surat Edaran } & \text { Kapolri } & \text { Nomor } \\
\text { SE/06/X/2015 } & \text { tentang } & \text { Ujaran } \\
\text { Kebencian (Hate } & \text { Speech) disebutkan } \\
\text { tentang Ujaran } & \text { Kebencian (Hate } \\
\text { Speech) } & & \end{array}$ & $\begin{array}{l}\text { Halaman }(3) \\
\operatorname{Huruf}(\mathrm{H})\end{array}$ & $\begin{array}{l}\text { Ujaran Kebencian (Hate Speech) dapat } \\
\text { dilakukan melalui berbagai media, antara lain: } \\
\text { 1. Dalam orasi kegiatan kampanye } \\
\text { 2. Spanduk atau banner } \\
\text { 3. Jejaring media sosial } \\
\text { 4.Penyampaian pendapat di muka umum } \\
\quad \text { (demonstrasi) } \\
\text { 5. Ceramah keagamaan } \\
\text { 6. Media masa cetak atau elektronik } \\
\text { 7. Pamflet }\end{array}$ \\
\hline
\end{tabular}

mempunyai kekuaatan hukum yang mengikat untuk itu dapat dilihat dalam aturan hukum pada undang-undang No. 19 Tahun 2016 atas Perubahan Undang-undang No. 11 Tahun 2008 tentang Informasi dan Transaksi 
Sedangkan penegakan hukum bagi pelaku ujaran kebencian dapat dijerat dengan undang-undang No. 19 Tahun 2016 atas Perubahan Undang-undang No. 11 Tahun 2008 tentang Informasi dan Transaksi Elektronik. Sebagaiman dengan Unsur-unsur tindak pidana ITE dalam Pasal 28 ayat (2) yaitu

1. Kesalahan : Dengan sengaja

2. Melawan hukum : Tanpa hak

3. Perbuatan : Menyebarkan

4. Objek : Informasi

5. Tujuan : Untuk menimbulkan rasa kebencian atau permusuhan individu dan/atau kelompok masyarakat tertentu berdasarkan atas suku, agama, ras, dan antar golongan (SARA).

Pasal 45 Undang-undang No. 19 Tahun 2016 atas Perubahan Undang-undang No. 11 Tahun 2008 tentang Informasi dan Transaksi Elektronik:

Ayat (1) Setiap Orang yang dengan sengaja dan tanpa hak mendistribusikan dan/atau mentransmisikan dan/atau membuat dapat diaksesnya Informasi Elektronik dan/atau Dokumen Elektronik yang memiliki muatan yang melanggar kesusilaan sebagaimana dimaksud dalam Pasal 27 ayat (1) dipidana dengan pidana penjara paling lama 6 (enam) tahun dan/atau denda paling banyak Rp1.000.000.000,00 (satu miliar rupiah).

Ayat (3) Setiap Orang yang dengan sengaja dan tanpa hak mendistribusikan dan/atau mentransmisikan dan/atau membuat dapat diaksesnya Informasi Elektronik dan/atau Dokumen Elektronik yang memiliki muatan penghinaan dan/atau pencemaran nama baik sebagaimana dimaksud dalam Pasal 27 ayat (3) dipidana dengan pidana penjara paling lama 4 (empat) tahun dan/atau denda paling banyak Rp750.000.000,00 (tujuh ratus lima puluh juta rupiah).

Ayat (5) Ketentuan sebagaimana dimaksud pada ayat (3) merupakan delik aduan.

Pasal 45 A Undang-undang No. 19 Tahun 2016 atas Perubahan Undang-undang No. 11

Tahun 2008 tentang Informasi dan Transaksi Elektronik:

Ayat (2) Setiap Orang yang dengan sengaja dan tanpa hak menyebarkan informasi yang ditujukan untuk menimbulkan rasa kebencian atau permusuhan individu dan/atau kelompok masyarakat tertentu berdasarkan atas suku, agama, ras, dan antargolongan (SARA) sebagaimana dimaksud dalam Pasal 28 ayat (2) dipidana dengan pidana penjara paling lama 6 (enam) tahun dan/atau denda paling banyak Rp1.000.000.000,00 ( Satu miliar rupiah ).

Dapat dilihat dari aturan pada pasal bagi pelaku yang melakukan ujaran kebencian sangat berat ancaman hukuman yang diterimah, untuk itu dengan adanya undangundang tersebut masyarakat dapat memahami dan dapat menggunakan media sosial dengan positif dan tidak mengandung muatan (SARA) dan mengakibatkan ujaran kebencian bagi orang lain.sehubungan aspek hukum telah mengaturnya.

\section{Upaya Penanggulangan Pelaku Pengguna Media Sosial Ujaran Kebencian?}




\begin{abstract}
Menuju kepada subtansi dari upaya penanggulangan pelaku pengguna media sosial ujaran kebencian, untuk dapat melindungi dari segala kepentingan masyarakat umum perlu butuh kerja sama antara jajaran pemerintah melalui penegakan hukum yang konsisten dan harus dilaksanakan dengan efektif dalam pelaksanaannya. Untuk itu negara telah menerbitkan aturan normatif dalam bentuk Undang-undang No. 19 Tahun 2016 atas Perubahan Undang-undang No. 11 Tahun 2008 tentang Informasi dan Transaksi Elektronik, subtansi dari isi aturan tersebut larangan bagi orang untuk melakukan ujaran kebencian yang diatur dalam:
\end{abstract}

1. UU ITE Pasal 28 ayat (2) menerangkan yang pada pokoknya memuat larangan menyebarkan informasi yang ditujukan untuk menimbulkan rasa kebencian atau permusuhan individu dan/atau kelompok masyarakat tertentu berdasarkan atas suku, agama, ras, dan antargolongan (SARA).

2. Sebaliknya Undang-Undang Nomor 40 Tahun 2008 tentang Penghapusan Diskriminasi Ras dan Etnis pengaturan dalam Pasal 4 dan Pasal 16 yang memuat larangan menunjukkan kebencian atau rasa benci kepada orang karena perbedaan ras dan etnis. Selanjutnya KUHPidana mengatur dalam Pasal 156, Pasal 157, Pasal 310, dan Pasal 311 pada dasarnya juga mengatur tentang larangan menyatakan perasaan permusuhan, kebencian, atau penghinaan terhadap suatu atau beherapa golongan rakyat Indonesia, menyerang kehormatan atau nama baik seseorang, serta melakukan fitnah.

Penanggulangan terhadap pelaku ujaran kebencian juga dapat dilakukan dengan cara mngedepankan fungsi dari aparat penegak hukum yang mana sebagai keamanan dalam negeri yaitu melalui Polisi Republik Indonesia (Polri), Selanjutnya wujud keseriusan Polri dalam memberantas Ujaran kebencian telah mengelurkan Surat Edaran Kapolri Nomor $\mathrm{SE} / 6 / \mathrm{X} / 2015$, tentang Penanganan Ujaran Kebencian (Hate Speech), tanggal, 8 Oktober 2015. Untuk itu dalam penanganan ujaran kebencian disebutkan pada:

1. Surat Edaran Kapolri Nomor $\mathrm{SE} / 6 / \mathrm{X} / 2015$, tentang Penanganan Ujaran Kebencian ( Hate Speech). Nomor. (5) Point (b), Halaman (4). isinya mengedepankan fungsi Binmas dan Polmas untuk melakukan penyuluhan atau sosialisasi kepada masyrakat mengenai ujaran kebencian dan dampak-dampak negatif yang akan terjadi.

2. Surat Edaran Kapolri Nomor SE/6/X/2015, tentang Penanganan Ujaran Kebencian (Hate Speech). Nomor. (5) Point (c), Halaman (4). Isinya mengedepankan fungsi Binmas untuk melakukan kerja sama yang konstruktif dengan toko agama, toko masyarakat, toko pemuda, dan akademisi untuk optimalisasi tindakan represif atas ujaran kebencian.

Menurut Asril, dalam Siddiq (2017:26). Sesuai dengan namanya WWW, yaitu World Wide Web, maka jaringan internet ini adalah selebar dunia. Hukum yang dibuat untuk mengatur internet di suatu negara dengan segera dan dengan sendirinya 
akan masuk kewilayah jurisdiksi negara lain. Tentu saja akan terjadi pertentangan, seperti yang dikatakan diatas, apa yang dilarang di Indonesia kemungkinan diwajibkan di negara lain.

Menurut Josua (2020:26), Secara khusus, perkembangan teknologi komputer dan internet memberikan implikasi-implikasi yang signifikan terhadap pengaturan atau pembentukan regulasi dalam ruang siber dan hukum siber serta terhadap perkembangan kejahatan dalam dunia maya (cyberspace), (cybercrimes).

Untuk penanggulangan ujaran kebencian jajaran perangkat pemerintah butuh dilibatkan seperti Kecamatan, Kelurahan/Kepala desa, Kepala Dusun/ Rukun Warga (RW), Kepala Lingkungan/Rukun Tetangga (RT). Seluruh jajaran ini dapat dilibatkan dalam upaya penanggulangan ujaran kebencian dan bekerja sama dengan Polri dalam memberikan Penyuluhan dan Sosialisasi di masyarakat. Dampak negatif terhadap ujaran kebencian dapat memecah belah bangsa, Untuk itu butuh penanganan serius dalam penanggulanagan ujaran kebencian. Lajunya pengguna Media sosial saat ini butuh perhatian yang cukup ketat untuk penanganan ujaran kebencian, sebaliknya konten-konten aplikasi yang tidak positif harus di non aktifkan atau di blokir oleh Negara melalui kementerian komunikasi dan informatika (Kemkominfo). Apalagi jika dilihat banyaknya konsumtif masyarakat menggunakan media sosial yang tidak tepat sasaran yaitu anak-anak dibawah umur dapat melihat dan mengakses berbagai situs-situs yang tidak mendidik, bahkan ujaran kebencian yang dapat memecah belah bangsa. Untuk itu Negara harus serius dalam penanggulangan ujaran kebencian.
Lupton dalam Wibowo (2018:172), Menambahkan bagaimana sebagian besar orang memiliki hubungan sosial dan emosional dengan komputer, bahkan dapat menghabiskan waktu di depan layar komputer lebih lama dari pada bertatap muka dengan orang lain. Lebih lanjut, Lupton mengilustrasikan jika komputer sebagai manusia (lebih tepatnya menubuh/embodied).

\section{KESIMPULAN DAN SARAN}

a. Kesimpulan

Dalam undang- undang No. 19 Tahun 2016 atas Perubahan Undang-undang No. 11 Tahun 2008 tentang Informasi dan Transaksi Elektronik. Dimana ujaran kebencian diatur dalam Pasal 28 ayat (2). "Menerangkan yang pada pokoknya memuat larangan menyebarkan informasi yang ditujukan untuk menimbulkan rasa kebencian atau permusuhan individu dan/atau kelompok masyarakat tertentu berdasarkan atas suku, agama, ras, dan antar golongan (SARA)". Jika dianalisa undang-undang cukup jelas bahwa perbuatan ujaran kebencian sangat dilarang oleh Negara untuk itu kepada lapisan masyarakat harus tanggap terhadap UU ITE, dimana ancaman hukuman juga diatur secara tegas dalam Pasal 45 A ayat (2) dan diatur dalam KUHPidana Pasal. 156, 157, 310 dan 311 KUHP. Selanjutnya dalam penanggulangan Pelaku Pengguna Media Sosial Ujaran Kebencian dapat bekerja sama Binmas dan Polmas (Polri) dengan toko masyarakat, toko agama, toko pemuda dan perangkat pemerintah.

\section{b. Saran}

Dalam penegakan hukum undangundang informasi dan transaksi elektronik terhadap hukuman pengguna media sosial ujaran kebencian butuh penegakan dan penindakan yang tegas terhadap masyarakat 
umum, khususnya pengguna media sosial. Untuk itu masyarakat harus diberikan kesadaran melalui penyuluhan dan sosialisasi tentang ujaran kebencian, dengan memberikan pengetahuan tersebut masyarakat dapat menggunakan media sosial dengan positif dan tidak mengandung konten negatif yang mengakibatkan ujaran kebencian (SARA).

\section{ACUAN REFERENSI}

Candem, 2009, Prinsip-Prinsip Camden tentang Kebebasan Berekspresi dan kesetaraan, Jurnal (UK: Article 19, April 2009), 11.

Chairul Huda, 2011, Dari Tiada Pidana Tanpa Kesalahan Menuju Kepada Tiada Pertanggungjawaban Pidana Tanpa Kesalahan, Kencana, Jakarta, 70.

Erika Dwi Watie, 2011, Komunikasi dan Media Sosial (Communications and Sosial Media), Jurnal The Messenger, Vol. III, Nomor I Edisi Juli, 69.

Gunawan, Heri (2020), Tinjauan yuridis terhadap ujaran kebencian (hate speech) di media sosial dikaitkan dengan kebebasan berpendapat dan undang-undang nomor 19 tahun 2016 tentang perubahan atas undang-undang nomor 11 tahun 2008 tentang informasi dan transaksi elektronik. Jurnal Res Nullius Law Journal, Vol. 2 No.1, Januari, 77.

Kitab-Undang-Undang Hukum Pidana (KUHP).

M. Choirul Anam dan Muhammad Hafiz, 2015, Surat Edaran Kapolri Tentang Penanganan Ujaran Kebencian (Hate Speech) dalam Kerangka Hak Asasi Manusia, Jurnal Keamanan Nasional Vol. I, No. 3, 344.
Nurhadiyanto, Lucky, 2019, Strategi Pencegahan Kejahatan Dengan Kebencian (Hate Crime) Melalui Media Mural di Kelurahan Kedoya Utara, Jakarta Barat, Jurnal Ikraith-Abdimas Vol. 2, No. 1, Maret, 5.

Prianter Jaya Hairi, 2019, Penanggulangan Tindak Pidana Terkait Ujaran Kebencian, pusat penelitian badan keahlian DPR RI, info singkat kajian singkat terhadap isu actual dan strategi, Vol. XI, No.03/I/Puslit, 4.

Surat Edaran Kapolri Nomor SE/6/X/2015, Tentang Penanganan Ujaran Kebencian ( Hate Speech).

Siddiq Nur Aisyah, (2017). Penegakan Hukum Pidana Dalam Penanggulangan Berita Palsu (Hoax) Menurut Undang-Undang No.11 Tahun 2008 Yang Telah Dirubah Menjadi Undang-Undang No.19 Tahun 2016 Tentang Informasi Dan Transaksi Elektronik, Jurnal Lex Et Societatis Vol. V/No. 10/Des, 26.

Sitompul, Josua (2012), Cyberspace, Cybercrimes, Cyberlaw Tinjauan Aspek Hukum Pidana, Tatanusa, Jakarta, 26.

Undang-Undang 19 Tahun 2016 atas Perubahan Undang-undang No. 11 Tahun 2008 tentang Informasi dan Transaksi Elektronik.

Wibowo, Okta Tanggu, (2018), Konstruksi Ujaran Kebencian Melalui Status Media Sosial, Junal Channel Jurnal Komunikasi, Vol.6, No.2, Oktober, 172 